\title{
The Shadow Pandemic: Examining the Impact of COVID-19 on Zimbabwean Informal Sector in Chiredzi District
}

\section{Bismark Mutizwa ${ }^{1}$}

${ }^{1}$ Public Administration, University of Zimbabwe. Zimbabwe.

Article History

Received:

07.01 .2021

Revised:

10.02.2021

Accepted:

18.04.2021

*Corresponding Author:

Bismark Mutizwa

Email:

bismarkmutizwa@gmail.com

This is an open access article, licensed under: $\mathrm{CC}-\mathrm{BY}-\mathrm{SA}$

(c) (i) (2)
Abstract: COVID-19 has disrupted the business sector globally, ushering developed and developing economies into an unprecedented recession beyond anything experienced in nearly a century. Governments across the globe have adopted a myriad of preventive measures. These remedial actions vary from one country to the other. Nonetheless, in Zimbabwe the government gave a blind eye on the informal sector as evidenced by the adopted preventive measures which neglected the plight of informal traders. To this end, this research interrogates the shadow pandemic in the Zimbabwean informal sector using Chiredzi District as an illustrative case study. Documentary review and key informed interviews were at the core of research methodology. The study found out that informal economy businesses are excluded from government grants, closure of businesses, failure to pay rentals, disruption of the supply chain, psychological impact and family dysfunctional are the quandaries causing a shadow pandemic. Inclusion of informal economy businesses in policies and government grants, government should negotiate with landlords, informal traders should be allowed to operate and inclusive social nets are the possible remedial actions that the government can adopted.

Keywords: Chiredzi District, COVID-19, Informal Economy, Informal Sector, Shadow Pandemic. 


\section{Introduction}

COVID-19 has put global economies on halt. The unprecedented grotesque and obnoxious impact of COVID-19 on developed, developing and even resource constrained states has undermined development and growth. Nations for some time embarked on a lockdown overdrive to curtail the spread of COVID-19. Industries, cities, schools and businesses are operating below optimum efficiency. The hypoxemia induced in the economy by COVID-19 has led to unaccounted loss of life, closure of industries, an increase in unemployment, poverty and destitution. Nevertheless, the impact of COVID-19 varies from country to country owing it to the development and growth of that nation. Nations such as South Africa, United State of America, Rwanda, China, Norway and Canada have made use of social nets or grants to help the under privileged. Large corporates and small businesses have also benefited from government loans and reduction in taxation. To this end, the Zimbabwean economy was not spared, the Ministry of Youth tried to give loans to youths but only a few had access to them. The Ministry of Small and Medium Enterprises also attempts to help those in Small and Medium Enterprises (SMEs) activities but the impact of COVID-19 remained unbearable. Therefore, it is against this background that this research seeks to interrogate impact of COVID-19 on the Zimbabwean informal sector using Chiredzi District as illustrative case study so as to offer viable remedial actions.

The history of the Zimbabwean informal economy or sector is problematic and controversial as its genes scintillate even prior independence [1]. Njaya [2] concurs with the above by noting that "In Zimbabwe the informal sector co-existed with the formal economy since time immemorial though at a very small scale up to the early 1990s." This narrative places the emergence of the informal sector or economy during the colonial era when industries and other businesses had been formalised. To this end, the informal sector encompasses other activities which were not formally recognised as integral components of the economy by the oppressive colonial system. Njaya [2] and Mhone [3] reinforces the above by noting that, "the informal sector comprised unregistered and unregulated entrepreneurs who chose to avoid registration and taxation." For Mkandawire [4] and Ndoro [5], the Rhodesian government condemned all other activities that were outside the main economic pipeline as a way of forcing blacks into wage employment. If one is to consider Mkandawire and Ndoro's perspective the informal economy was already operational during the colonial era although it was deemed illegal.

The above narrative purports that, the main economic activities which consisted industries and business that were registered dominated the cities and towns while the informal economy activities dominated the rural areas as it was considered illegal. The whole economic sector was tailor-made in a sophisticated manner that infused dependency syndrome and systematically disempower the black majority. Soderbaum [6] reinforces the above view by articulating that African states are pigeonholed by a plethora of informal activities unlike in developed nations where formal economy takes precedence. In developing nations formal economy is still playing a limited role as compared to informal economy. This is because formal economy activities are largely confined in towns and cities while neglecting the rural areas yet the majority of the African population lives in rural areas and their lives is sustained through a sophisticated informal economy channel. Therefore, this explains the failure by many African governments to construct a vigorous formal economy after attaining independence.

Nonetheless, just like many African governments upon attaining independence the Zimbabwean government failed to develop a sophisticated model of economy that sustains development in rural areas and towns as adopted in Singapore and South Korea. To this end, the Zimbabwean informal sector has been propelled by quandaries and quagmires in the formal sector that led to the closure of many industries and lay off of workers [2] [7]. Therefore, underemployment, unemployment, gender inequality, poverty, as well as precarious work are the enzyme that makes informal economy flourish. It is imperative to note that these are the very circumstances that have dominated the Zimbabwean economy [2] [8] [9] [10] [11]. The uncontrollable vicissitudes in the Zimbabwean political and socioeconomic landscape has led to the proliferation of the informal economy activities as people sought to survive. The informal sector has contributed immensely to the growth and development of Zimbabwe. In 1980, the informal economy contributed $10 \%$, in 1986 and $198720 \%$, in $199127 \%$ and in 2000 $60 \%$ since then it has never dropped [1].

Mutizwa [12] noted that, the emergence of the $21^{\text {st }}$ century ushered Zimbabwe into an unprecedented closure of industries, loss of revenue and international isolation authored by the imperialist ink under the lenses of the Zimbabwe Economic Recovery Act (ZIDERA). All the same, 
the whole scenario is debatable and controversial as the Zimbabwean public sector was characterised by "corporate governance epidemics", it is equally important not to down play the role played by Economic Structural Adjustment Programme (ESAP) 1990-95 in laying off many workers from the private and public sector [11]. The land reform program also fuelled the growth of the informal sector. This is because many people were left jobless after farms were invaded. The invasion of farms and closure of industries led to the mass exodus of Zimbabweans into other countries while those who remain sought for survival in the informal economy [2] [11] [13].

As of June 2005 approximately 3 million out of 11 million people depended on the informal economy for survival [8]. Chilunjika \& Mutizwa [11] articulated that unemployment increased during the 2008 hyperinflation. Njaya [2] and Dekker [14] concurs by noting that between 2007-2008 unemployment rate was between $80 \%-94 \%$. Ndiweni and Verhoeven [1] and Multi Donor Trust Fund (MDTF) [15] postulates that the during the hyperinflation period, inflation reached 11 million percent by the end of May and 231 million which was the highest by July 2008, a 75\% decrease in gold production was recorded and $90 \%$ decrease in industry capacity utilisation. It is against this cataclysmic atmosphere that informal entrepreneur in Zimbabwe was born as a survival strategy. The Zimbabwean informal economy plays an essential role in income generation as a result of the ease entry and less demands for skills, education, capital and technology. All the same, many Zimbabweans join the informal economy by necessity to withstand the hostile effects of poverty, inflation and unemployment as a survival strategy and not by choice [16]. Therefore, with the reintroduction of the lockdown moratorium as of 4 January 2021, informal economy activities have been interrupted again threatening livelihoods of people who depend on it. Thus it is the duty of this study to interrogate the impact of COVID-19 on the Zimbabwean informal economy focusing on Chiredzi District with the intention of generating viable recommendations.

The study examines the impact of COVID-19 on the Zimbabwean informal sector using Chiredzi District as illustrative case study. The study is worthwhile and timely as researches that focuses on the impact of COVID-19 on informal sector are still burgeoning and mushrooming. The study is imperative not only because it is examining events as they unfold but because the research catchment area is usually neglected and attention is given to big cities and towns. Therefore, the findings of the study can be used as a reflection of all other small towns and districts that are usually neglected when researches are conducted. The findings of the study can be generalised to other districts and also used as a springboard for further studies on how epidemics and pandemics can interrupt the informal sector and causing unbearable loss of revenue. The remedial actions proposed by the study will inform public administrators and policy makers on how to respond to future epidemic and pandemic impact on the informal sector.

\section{Literature Review}

\subsection{The Concept of Informal Sector/ Economy}

Globally, the informal sector provides the biggest share of employment approximately $61.2 \%$ of the total employment population [7]. The informal economy is imperative to job income as well as consumption of poor men and women. The term informal sector and informal economy are habitually used interchangeably. The concept of the informal sector has been problematic since its emergence in the 1970s in Africa [16] [17]. This is because there are various perspective that have been put forward and one can choose anyway that he want to observe it. Hussmanns [18] presents a four dimensional perspective into the informal economy that is: it can be viewed as a fecund ground for entrepreneurship, it can be regarded as that component of the society that evade taxes and regulations, it can also be viewed as an enabler of child labour and all forms of precarious working condition lastly it can been regarded as a sector that provides hope and employment to those who might have been condemned by the formal sector.

Despite the debate that surrounds its emergence and what it constitutes, the informal economy is a global phenomenon that is not limited or associated to one nation. Organisation for Economic Cooperation and Development (OECD) [19] noted that, the $15^{\text {th }}$ International Conference of Labour Statisticians in January 1993 adopted the International Labour Organisation Resolution Concerning Statistics of Employment in the Informal Sector which pigeonholed the informal economy as unregulated components betrothed in the production of services and goods with the intention of creating employment and generating revenue for all parties involved. These unregistered components 
function with little or no division of labour at all and production is usually at a small scale and operating at the low level of organisations [20] [21].

In line with the above narrative, the informal sector is regarded as that business ecological sphere that is characterised by self-employment, unregulated, small scale production, labour is not protected and use of simple technology [3]. If developing nations can fully comprehend and harness the informal sector into the mainstream economy, there is no doubt that the world will witness the transmogrification and metamorphosis of developing states into developed states. This is because the informal economy has remained one of the untapped avenues of revenue that can help government to capacitate its departments; sponsor projects boast its Gross Domestic Product (GDP) culminating in the development and growth of a nation. Stuart et al [22] to this end, regarded the informal economy as the new normal that should be embraced by nations across the globe if there are to register spontaneous growth and development.

\subsection{The Impact of COVID-19 on Informal Economy in Developed Nations}

Stuart et al [22] noted that, in developed nations the informal sector has been embraced as the new normal. Developed economies have propagated the inclusiveness of the informal sector into the mainstream economy for growth and progressive [23]. The informal sector is regarded as the integral component of the economy that contributes effectively to national growth and development. The informal economy should never been measured using the parameters or the yardstick of the formal economy, it should be assessed based on its on contribution to the GDP comparing with the formal economy will be a misnomer. Holmes \& Scott [24] articulated that, developed economies managed to enhance growth and development by extending social insurance to informal workers. Thus capacitating and revitalising their work engagement which is prerequisite for robust job satisfaction. It is against this backdrop that, developed economies unveiled social nets that cover the informal economy during the pandemic. Thus the impact of COVID-19 on their informal sector is less as compared to those in developing economies as they had been recognised as an integral part of the mainstream economy.

In addition, United Kingdom (UK), United States of America (USA), Canada and Norway constantly engage members of the informal sector in various capacitating seminars and programs [25] [26] [27]. There are constantly empowered with the right knowledge to save and insure their businesses in case the worst happen. Vingirayi, et al [20] is of the view that, although developed economies 'informal sector has been hit hard by the pandemic, it has also proved how sustainable they are, as compared to developing informal sector. Most of the businesses are informal yet insured, apart from that their governments have provided all citizens with sufficient stimulus packages to help them throughout the pandemic. African Union [29] stated that, "France announced 334 billion Euro as response to COVID-19, Germany 13.38 while England reduced interest from $0.75 \%$ to $0.25 \%$ and 37 billion as a response to COVID-19. All these stimulus packages also helped in protecting those who are in the informal sector. In this regard, Africa and other developing nations should therefore mimic the informal economy model of developed nations for future epidemic and pandemic management.

\subsection{The Impact of COVID-19 on Informal Economy in Developing Nations}

The pandemic is impacting negatively not only the informal economy but the mainstream economy "beyond anything experience in nearly a century" (Congressional Research Services Report 2020). United Nations (UN) [30] noted that the impact of the pandemic in Africa was felt way before it reached the continents shores, economies and livelihoods were destroyed. This was due to the lockdown which culminated in the closure of industries, economies, boarders and airspace [12]. Consequentially, this led to the decrease in demand for Africa's products and collapse of tourism due to the of reduction of international flights. The decrease of tourists had a huge impact on the African informal economies which are the biggest suppliers of organic foods and African traditional arts to tourists.

UN [30] articulated that, what makes the African question peculiar is the nature of her informal sector. ILO [28] noted that:

\footnotetext{
"Informal employment is the main source of employment in Africa, accounting for 85.8 per cent of all employment. In other words, informal economy in Africa is not a marginal
} 
phenomenon, but rather the space where the majority of working men and women sustain themselves."

The majority of African and Latin American people depend on the informal economy, people in the informal economy make use of less technology and much of their own hands and what is worrisome is the fact that many of them have less or no insurance at all against unexpected disruptions [31]. Africans and Latin Americans who are in the informal sector are not there by choice [32]. The informal economy has been embraced as a survival strategy to circumvent poverty and unemployment. Rukundo [33] propounded that, "the informal sector plays an important role in African economies accounting for a large share of gross domestic product (GDP) and even greater share of employment." Therefore, Africans cannot comply with lockdown regulations for example stay-at-home and social distancing without austere ramification on their livelihoods [30]. In 2019, the informal economy had contributed immensely to the growth of developing economies. IMF [37] had projected a growth of the fiscal balance to GDP to rise from $4.8 \%$ to $91 \%$ thereby contributing effectively to domestic mobilised revenues. The developing economies in questions include Zimbabwe, Iran, South Africa, Venezuela, Jordan, Argentina and Lebanon [38].

\section{Rwanda}

In Rwanda, the informal economy plays a significant role in the development of the nation. The informal sector contributed about $64 \%$ of industry output [33]. Godfrey [34] is of the view that, being informally employed does not translate to poverty, exclusion from public services and social security or entails low productivity. The informal sector of Rwanda encompasses small-scale entrepreneurs who have greater capacity for growth and innovation. Therefore, the lockdown at subnational and national level as well as prohibition of peoples movement especially those in non-essential services or those in formal services has impacted negatively on the informal sector of Rwanda. Many have lost their jobs, failed to pay rentals, food insecurity and facing extreme poverty. Even so, to circumvent these quandaries Rwanda has established the Social Protective Plan for the delivery of food across Kigali. Mutizwa [12] supports the above view by articulating that through the COVID-19 Emergence Response Project Rwanda has managed to sustain its economy through various schemes, food donations and small grants to those in business sector include those in the informal economy. Nevertheless, not all those in the informal sector benefited from the government donations and grants. Thus many are still left at the inimical and malevolent mercy of the pandemic that has terrorise people`s livelihoods.

\section{Nigeria}

The informal economy in Nigeria just like in many Sub Saharan nations accounts for the large part of the economy. The Bank of Industry in Nigeria recognises the informal economy as an essential economic drive that contributes approximately $65 \%$ to the GPD [35]. Just like in Nigeria, in Uganda approximately 13.7 million of the population between the ages of 14-64 which is the working age are active in the informal economy which is about $98 \%$ population of the total working age. The pandemic like in other nation had impacted the demand and supply matrix. There is a spontaneous decrease in the demands of good by industries and public at large which has affected the sales of those in informal businesses. This has led to the increase of poverty, destitution, food insecurity and failure of many informal businesses which are the pipeline of survival for many families. Currently, the Nigerian government has done little to cater for those in the informal economy. Therefore, for survival, the government need to put in place safety nets that account for all who cannot access the CBN N50 Billion COVID-19 Credit Facility. Oluwase \& Ademola [35] noted that "If the stimulus package is implemented in its current form, large proportions of informal workers particularly in Lagos, who depend mostly on irregular daily wages with almost no safety nets to depend on will be left to fend for themselves." Failure to do so will culminate in the increase of crime rate, prostitution and destitution.

\section{Methodology}

The study benefited from documentary review and key informed interviews. The research had a drawback in data gathering due to the national lockdown. However, the data attained through purposive and convenient sampling from Rupanganwa business centre (Save), Triangle, Hippo 
Valley, Tshovani and Chilonga was sufficient to come up with a meticulous and comprehensive study that answered the following questions. What is the impact of COVID-19 on the businesses in Chiredzi District? What is the nature of the challenges being encountered by business people during the lockdown? What are the possible solutions government should be doing to help businesses? The views of Chiredzi District residents were imperative in providing an insight into the impact of COVID-19, the nature of the challenges and possible ways to circumvent similar quandaries in the future. Content and thematic analysis was used to evaluate the findings.

\section{Findings and Discussion}

\subsection{Presumptive Tax}

The year 2005 saw the introduction of presumptive tax by the government in an attempt to broaden its tax base by targeting the informal sector. "The presumptive tax is based on presumed (average) income of those persons engaged in any trade specified in the Income Tax Act (chapter 23:06) as opposed to actual income" [36]. The area of the informal sector which a trader belong to determine the rate to be used to calculate the actual tax that the trader is required to pay. Informal traders pay various presumptive taxes which includes: cross-border presumptive tax, market fee and hawker licence, associated toilet fees, storage fees and the $2 \%$ tax on every electronic transfer they make to mention but a few. Although presumptive tax helps in broadening the nation's fiscal space, it had grave ramifications on the livelihoods of informal traders as the government continued to tax them heavily as evidenced by the period when the lock down was lifted. The little profits they were making and trying to recover from the first lockdown the government comes and tax them heavily. To this end, with the re-introduction of the lockdown as of 4 January 2021, an unprecedented shadow pandemic has been reactivated as informal traders did not have enough time to recover from the first lockdown and save for future emergencies.

\subsection{Informal Economies Businesses Are Excluded From Government Grants}

The research learnt that, most policies excludes the informal economy yet it plays significant role in the growth and development of the national GDP. The ZWL\$18 billion Economic Recovery and Stimulus Package announced by the President on the $1^{\text {st }}$ of May 2020 did less for the informal economy. Zimbabwe's formal sector has been greatly destabilised by the erratic policy environment coupled with international isolation. It is against this backdrop that the informal sector was embraced by many as a curative and survival strategy. Key informed interviews conducted with residents from Triangle, Hippo Valley, Tshovani and Chilonga exposed how the informal sector is being alienated during the pandemic. The respondents noted that their situation became hopelessness after the announcement of the ZWL\$18 billion Economic Recovery and Stimulus Package which gave only ZWL $\$ 0.50$ billion to the Small to Medium Enterprises (SMEs) yet there are the biggest sectors of the economy. Youths from Chilonga, expressed anger and displeasure towards what they call "the pandemic war by the state" as they did not benefited from the ZWL 17 million Youth Relief Fund. They asked a series of rhetoric questions; if we can be neglected in the first relief fund what guarantee do we have that we are going to receive fund this time around. This view was reinforced by youths from Hippo Valley who argued that youths in the informal sector constitute the biggest part of the population and by that virtue we pay tax more than the older generation. It would only be fair if we are to be given assistance when others get it. This argument is water tight, the failure by the government to genuinely provide a reasonable amount to the informal sector spells a shadow pandemic that if not attended to will cause untold suffering in Chiredzi District and stimulate an obnoxious and repugnant atmosphere.

In addition, government grants do not simply mean loans from the state. It encompasses a myriad of restraints such as the inability to attain government contracts during the pandemic, failure to access viable government lines of credit and inability to partake in donor-funded programs. This spells doom on informal sector businesses as they are excluded formally from the capacity building projects that would have bring about transmogrification in their business operations. It is rather worrisome that, the Chiredzi District informal sector is excluded in major government grants and projects yet every now and then attempts are made to formally tax them and their contribution to the GDP is formally recorded. The research learnt that those in the informal economy business in Chiredzi District feels neglected during this pandemic and government policies are not being inclusive. 


\subsection{Closure of Businesses}

The informal economy is the new normal [22] [23]. The sooner the government embrace that reality and an opportunity for growth and development the better for the nation. The study learnt that the informal sector is the nerve centre of growth and development sustaining over forty thousand families directly and indirectly in Chiredzi District. The adopted COVID-19 preventative measures by the government which includes an overdrive international and national lockdown, prohibition of movements from city to city coupled with social distancing and a 6 am $-6 \mathrm{pm}$ curfew a had grave impact on many informal businesses in Chiredzi District. The closure had devastating impact on the families that depended upon the businesses as most of them were family run businesses. The research discovered that at Rupanganwa business centre (Save) most businesses were being managed by women while their husbands popularly known as "majoni joni" in the native language were in South Africa providing all the financial support and purchase of new stocks. The lockdown affected the movement of goods from South Africa to Zimbabwe thereby interrupting the purchase of new stock culminating in the closure of businesses. To the Chiredzi District informal sector businessman and businesswomen, the closure of their businesses meant the closure of their source of income and livelihoods. It meant exposing them to the inimical, aspersive and malevolent effects of poverty and destitution. "Musika wematanda", Dulis and "Magaraji" are some of the popular places closed in Chiredzi District.

\subsection{Failure to Pay Rentals}

The unfortunate closure of informal sector businesses had detrimental effects on the people's income. The study discovered that many vendors, informal sector traders, carpenters and mechanics have been gravely affected by the pandemic. The on-going lockdown moratorium led to the closure of their businesses as aforementioned culminating in their failure to pay rentals. Majority of vendors in Thsovani do not own houses therefore, there are tenants. What is worrisome is their inability to pay rental fees which has led to a rift between many tenants and landlords. The research learnt that some tenants were already serving their three months' notice after failing to pay rentals. The study regard this as a shadow pandemic because many people's attention has been shifted and there are not even aware of the predicaments, suffering and destitution that is being encountered by vendors. The right to shelter is recognised by the International Declaration of Human Rights and is classified under second generation rights. Therefore, it is against this backdrop that one can argue that the impact of the pandemic has induced unprecedented suffering and violation of human rights in Chiredzi District.

\subsection{Disruption of the Supply Chain}

The lockdown destabilised the supply chain, many of informal traders, vendors, mechanics and carpenters get their resources from South Africa. Chiredzi district enjoys considerable support from the South African economy due to its proximity to the nation. The delivery was being contacted by individual that were in informal cross boarder trading popularly known as "runners". People make their orders to runners who go to South Africa and bring their supply. Therefore, with the current lockdown both the runners and other informal traders cannot cross the border. What it means is that the runners are out of businesses and so are the informal traders. The disruption of the supply chain is far beyond what it spells on the surface, it is the disruption of the informal traders' survival strategy, it symbolises doom on their side as the unavailability of supply culminates in the closure of their businesses.

\subsection{Psychological Impact}

Interviews with businessman and businesswoman in the informal sector in Chirediz District were filled with trepidation, unease and bewilderment as to what will become of them due to the poverty, destitution and predicament induced in their lives by the shadow pandemic which is the impact of COVID-19 on their businesses. Depression and anxiety which are consequences of the shadow pandemic is causing unprecedented high blood pressure, melancholy, misery and unhappiness due to the demise of informal sector businesses which was the peoples source of livelihood. Psychologically, many informal traders have been broken down as they do not know what will become of them and their families. The study learnt that the impact of COVID-19 is causing more quandaries and suffering in the same manner COVID-19 is causing to the families of those who might have lost their relatives. 


\subsection{Family Dysfunctional}

Family dysfunctional was discovered to be one of the most devastating effects of the pandemic in Chiredzi District. Closely related to the psychological impact being induced by the pandemic is family dysfunctional. The study learnt that, Gender Based Violence (GBV) is increasing, mothers are now shouting at their husband to provide for the family at the same time the fathers who are supposed to be providers are failing due to circumstances beyond their control. Prostitution and crime is increasing as people seek to survival in this brutal pandemic. Therefore, unfaithfulness on the part of other spouse to feed the family is the major cause of family schism.

\section{Conclusion}

While the nation is focused on COVID-19, there is a shadow pandemic that has caused unprecedented suffering in the informal sector. The informal sector is the most affected sector in Chiredzi district and much need to be done to revive it and sustain families. The focus of the study on Chiredzi district was prompted by the fact that, small towns are usually neglected in researches and government projects. Therefore, the study unearthed a myriad of quandaries and predicaments as aforementioned for the purpose of bring about robust remedial actions. There are few recommendation:

- Rationalisation of the Presumptive Tax

The government should rationalise the presumptive tax according to informal traders' expenses and livelihoods. The presumptive tax cost should not be more than the profits that one makes. In the case of informal traders the government should align presumptive tax with the poverty datum line.

- Inclusion of Informal Economy Businesses in Policies and Government Grants There is need for the government to understand that the informal sector is the new normal. As such it is imperative that the government capacitate them through government grants so as to harness their skills and contributions to national development and growth. Government should also include informal sector in its policies. This has been done in nations such as United Kingdom, Australia and Canada. It is worth noting that the results were positive. The issue of closure of business will also be addressed by the remedial action.

- Government Should Negotiate With Landlords

There is need for the government to engage landlords. One of the key responsibility of the government is to ensure for the social well-being of its citizens. Therefore, a lucrative agreement between the state and landlord should be reached for landlords to charge half prices of rentals during the pandemic and only return to normal charging post pandemic.

- Informal Traders Should Be Allowed To Operate

Government should see to it that, members of the informal sector are allowed to operate provided they upholding COVID-19 regulations as prescribed by the international, continental, regional and national health regulators. This is because those who are in the informal economy are not there by choice but as a survival strategy to curb the inimical effects of poverty and destitution. Therefore, government should open informal sector while making sure that the one metre distance is maintained, mask are put on, hands are constantly sanitised, isolation for the rest of the population except for those who are in serious need of informal economy services.

- Inclusive Social Nets

The government should see to it that every attempt to give citizens grants should be an apolitical process. This is because the pandemic does not alienate people based on political affiliation. Nations such as Rwanda, South Africa, USA and China have given their citizens grants to curb the devastating effects of the pandemic. An examination of the grant distribution process shows that, if distributed in a transparent and accountable manner the effects of the pandemic might be minimised.

\section{References}

[1] E. Ndiweni, and H. Verhoeven, "The rise of informal entrepreneurs in Zimbabwe: evidence of economic growth or failure of economic policies", African J. of Accounting, Auditing and Finance, 5(2), 2021. 
[2] T. Njaya, "Informal Sector, Panacea to the High Unemployment in Zimbabwe? Case of Informal Sector Enterprises of Harare Metropolitan", International Journal of Research in Humanities and Social Studies, vol. 2, no. 2, pp. 97-106, 2015.

[3] G. C. Z. Mhone, E. S. A. P. Can, "Sustainably transform the non-formal sectors in Zimbabwe?", SAPEM, 7, 1994.

[4] P. T. Mkandawire, "The Informal Sector in the Labour Reserve Economies of Southern Africa with Special Reference to Zimbabwe”. Zimbabwe: ZIDS, 1985.

[5] H. Ndoro, "Zimbabwe: the informal sector in a decontrolling formerly socialist economy", in Mhone, G.C.Z. (Ed.): The Informal Sector in Southern Africa, pp.21-54, Sabe Books, Harrare, 1996.

[6] F. Soderbaum, "Blocking human potential: how formal policies block the informal economy in the Maputo corridor", in Guha-Khasnobis, B., Kanbur, R., Ostrom, R. and Corridor, E. (Eds.): Linking the Formal and Informal Economy: Concepts and Policies, pp.163-179, Oxford University Press, Oxford, 2007.

[7] T. Mudamburi, "Sustainable millennium framework for managing entrepreneurship in developing countries in Africa (Zimbabwe case study)", Journal of Global Entrepreneurship, vol. 2, no. 1, pp. 9-20, 2012.

[8] K. Ngundu, "The Impact of the Informal Economy on the Social and Economic Development of Women Headed Households in Chegutu Urban District in Zimbabwe", Unpublished Dissertation MSW Social Development and Policy, University of Pretoria, 2010.

[9] D. Coltart, "A Decade of Suffering in Zimbabwe, Center for Global Liberty \& Prosperity-Development Policy Analysis", the Cato Institute, no. 5, March 2008.

[10] A. Chilunjika, "From corporate mess to corporate hygiene: dealing with corruption in Zimbabwe's public sector", Journal of Public Administration and Development Alternatives (JADA), vol. 3, no. 2, pp. 52-72, 2018.

[11] A. Chilunjika, and B. Mutizwa, "Exploring factors militating against the performance of parastatals in Zimbabwe: the case of the national railways of Zimbabwe from 2008 to 2016", Journal of Public Administration and Development Alternatives (JPADA), vol. 4, no. 2, pp. 4160, 2019.

[12] B. Mutizwa, "COVID-19 a Global Nightmare: Revamping the Zimbabwean Health Sector (ZHS) for Future Epidemic and Pandemic Management", Journal of African Problems \& Solutions (JAPS), vol. 2, no. 1, pp. $59-73,2020$.

[13] J. Crush, and D. Tevera, "Zimbabweans Who Move: Perspectives on International Migration in Zimbabwe, Southerns Africa Migration Project. [Online] Available: http://www.queensu.ca/ samp/sampresources/samppublications/policyseries/Acrobat25.pdf, [Accessed: 2002].

[14] M. Dekker, "Livelihoods and Economic Crisis: The Case of Smallholder Farmers in Zimbabwe (1999-2008) in Centre for the Study of African Economies", University of Oxford, Oxford, 2009

[15] MDTF, “Zimbabwe Emergency Recovery Program, Draft 2, September”, Harare, 2008.

[16] P. Chibisa, and C. Sigauke, "Impact of Operation Murambatsvina (Restore Order) on Flea Markets in Mutare: Implications for Achieving MDG 1 and Sustainable Urban Livelihoods", Journal of Sustainable Development in Africa, vol. 10, no. 1, pp. 31-65, 2008.

[17] "International Labour Organisation. Women and Men in the Informal Economy: A Statistical Picture, Employment Sector", International Labour Office, Geneva, 2002.

[18] R. Hussmanns, "Informal Sector: Background and statistical definition. Paper presented during a seminar on the informal sector", Bamako, 10-14 March 1997.

[19] OECD. "Measuring the Non-Observed Economy: A Handbook", Paris: OECD Publication Service, 2002.

[20] I. Vingirayi, O. Hapanyengwi, B. Nyagadza, and N. Nyamuraradza, "Zimbabwean Informal Sector ZIMRA Tax Revenue Collection Barriers", Journal of Global Economics, Management and Business Research, vol. 12, no. 2, pp. 14-25, 2020.

[21] W.V. Mitullah, "Street Vending in African Cities: A Synthesis of Empirical Findings from Kenya, Cote Divoire, Ghana, Zimbabwe", Uganda and South Africa, University of Nairobi. Institute of Development Studies, 2003.

[22] E. Stuart, E. Samman, and A. Hunt, "Informal is the new normal Improving the lives of workers at risk of being left behind, London", Overseas Development Institute, 2018. 
[23] J. Heintz, "Informality, inclusiveness and economic growth: an overview of key issues", Amherst: University of Massachusetts Political Economy Research Institute, 2012.

[24] R. Holmes, and L. Scott, "Extending social insurance to informal workers a gender analysis. ODI working paper 438. London: Overseas Development Institute, 2016.

[25] A. Adams, "Improving skills development in the informal sector: strategies for sub Saharan Africa", Washington DC: World Bank, 2008.

26] A. Adams, S. J. De Silva, and S. Razmara, "Improving skills development in the informal sector: strategies for subSaharan Africa. Washington DC: World Bank, 2013.

[27] ILO \& IYF "Upgrading informal apprenticeships in Jordan: Key findings from a pilot study. [Online] Available: http://www.iyfnet.org/sites/default/files/library/ILOIYF_EquipYouth_ Pilot_Study_Report.pdf, [Accessed: 2015.]

[28] ILO "Women and men in the informal economy: a statistical picture", International Labour Organisation, 2018

[29] African Union. "Impact of Coronavirus (COVID-19) on the African Economy, Addis Ababa, 2020.

[30] "United Nations Women in informal economy. [Online] Available: https://www.unwomen. org/en/news/in-focus/csw61/women-in-informal-economy [Accessed: 2020].

[31] A. Hunt, and E. Samman, "Women's economy empowerment: navigating enablers and constraints. London: Overseas Development Institute, 2016.

[32] Gallup, Inc. and the International Labour Organization, Towards a better future for women and work: voices of women and men. Geneva: ILO, 2017.

[33] J., B. Rukundo, "Understanding Informal sector Employment in Rwanda" International Review of Research in Emerging Markets and the Global Economy (IRREM), vol. 1, no. 2, pp. 295$305,2015$.

[34] P. C. Godfrey, "Toward a Theory of the Informal Economy", the Academy of Management Annals, vol. 5, no. 1, pp. 231-277, 2011.

[35] B. Babajide Oluwase, and W. A. Ademola, "COVID-19 and the Lagos Informal Sector Realities, Implications and Response. [Online] Available: https://www.researchgate.net/ publication/340941266, [Accessed: 2020].

[36] International Centre for Tax and Development, "Expensive to be a Female Trader: The Reality of Taxation of Flea Market Traders in Zimbabwe," 2019.

[37] IMF, "Fiscal Monitor, Statistical Appendix," Washington DC: IMF, 2020.

[38] R. Wigglesworth, Long Live Jay Powell, the New Monarch of the Bond Market, Financial Times. [Online] Available: https://www.ft.com/content/5db9d0f1-3742-49f0-a6c16c471875b5e [Accessed: 2020]. 